\title{
EFFECT OF BAGWORM Pteroma pendula Joannis ATTACK ON THE DECREASE IN OIL PALM PRODUCTIVITY
}

\author{
Hari Priwiratama, Tjut Ahmad Perdana Rozziansha, Agus Eko Prasetyo, \& Agus Susanto
}

\author{
Indonesian Oil Palm Research Institute \\ Jl. Brigjen Katamso No. 51, Medan 20158 \\ E-mail: hari.priwiratama@gmail.com
}

\begin{abstract}
Effect of bagworm Pteroma pendula Joannis attack on the decrease in oil palm productivity. Outbreak of oil palm bagworm Pteroma pendula has been reported within the last few years in several plantations in North Sumatra. A study was conducted to determine the impact of $P$. pendula attacks on oil palm productivity. Aerial photograph was taken in November 2016 and analyzed to determine the level of damage on each palm canopy. The damage symptoms were classified onto healthy palms as control plants (score 0 ), mild (score 1), moderate (score 2), severe (score 3), and very severe (score 4). The sample palms were randomly selected and observed for the sex ratio, bunch number and bunch weight at 18 months after defoliation. The attack of $P$. pendula at the highest level (score 4) caused a significant effect on sex ratio and the number of bunches produced. The fresh fruit bunches production was declined $21.02-36.35 \%$ on palms with moderate to very severe attack (score $2-4$ ). Similar palms also have a potential case of inflorescences abortion 18.41-32.54\%. However, the average bunch weight was not influenced by $P$. pendula attack.
\end{abstract}

Key words: bunch number, bunch weight, Pteroma pendula, sex ratio

\section{INTRODUCTION}

Pest attack is one of the limiting factors in the cultivation of oil palm. Damage due to pest attacks have a negative impact on the production of oil palm fresh fruit bunches (FFB), both directly and indirectly. Direct yield loss can occur due to pests on flowers and fruit bunches, such as the oil palm bunch moth Tirathaba ruvifena Walker and mice (Corley \& Tinker, 2015; Masijan et al., 2015). Decreased FFB production can also occur indirectly as a result of severe damage to oil palm leaves (Chung, 2015; Woittiez et al., 2017). Damage to the leaves will cause disruption of the photosynthesis process so that the supply of assimilates for fruit development is reduced (Ajambang et al., 2015; Apichatmeta et al., 2017). Damage to the leaves can also cause palm to become stressed so that they tend to form male flowers.

In general, pest attacks on oil palm plantations in Indonesia are dominated by leaf defoliating pests, especially from the Lepidoptera such as nettle caterpillars, tussock moths, and bagworms (Susanto et al., 2015). Of the three caterpillars, bagworm is the most difficult to control in the field. Some of the dominant species of bagworms in oil palm plantation are Metisa plana Walk., Pteroma pendula Joannis, Mahasena corbetti Tams., and Clania tertia Temp. (Susanto et al., 2015; Priwiratama et al., 2018). Among these, P. pendula has the smallest size and it is quite rare to report its population explosion in the field. However, since the last five years the $P$. pendula attack has been reported in several plantations in Deli Serdang Regency, North Sumatra (Pangaribuan et al., 2017) and until now the attack can still be found in the field.

There have not been many studies on the impact of $P$. pendula attacks on the productivity of oil palm. Knowledge on the correlation between attack intensity and crop productivity is very useful for predicting potential yield losses due to $P$. pendula attacks. This study aimed to determine the level of decline in oil palm productivity due to $P$. pendula attacks.

\section{MATERIALS AND METHODS}

The study was conducted at one of oil palm plantations in Deli Serdang Regency, North Sumatra $\left(3^{\circ} 21^{\prime} 01.3^{\prime \prime} \mathrm{N}, 99^{\circ} 07^{\prime} 01.5^{\prime \prime} \mathrm{E}\right)$. The type of soil in the most of the experimental sites was red-yellow podzolic with an average rainfall of $1,900-2,482 \mathrm{~mm} /$ month. The observation site was a 10 ha block of mature oil palm planted in 2013. Photographs of bagworm attacks at the observation site were carried out using drones in November 2016, while the calculation of the sex ratio of oil palm was carried out in April to May 2018.

Scoring of the Level of Oil Palm Damage Due to P. pendula. Scoring of the level of oil palm damage due to bagworm $P$. pendula was carried out based on 
the symptoms of the attack on the oil palm canopy seen in aerial photographs taken on November 2016. Scoring criteria used are presented in Table 1. The map of damage intensity was then arranged based on the results of the scoring to see the distribution of each category of damage in the field. After the map was obtained, verification in the field was performed to ensure the accuracy of the scoring that has been carried out on affected palm.

Determination of Sample Plots. After the verification, 120 palm samples for each scoring category (Table 1) were randomly selected by considering the similarity between palms. Upkeep for all plot samples including fertilization, pests and diseases control, weeding, frond pruning, and FFB harvesting activities were carried out according to local estate standards and policies.

Observation of Sex Ratio and FFB Production of Oil Palm Infected by $P$. pendula. An evaluation of the impact of leaf eating caterpillars on the sex ratio of oil palm was carried out 18 months after defoliation. This is based on the process of sex differentiation that occurs in the period of 18-30 months before the appearance of the oil palm inflorescences (Harahap, 2008). Observation of sex ratio was conducted by counting all male and female inflorescences, and FFB produced by each sample. The value of sex ratio is calculated by the following formula (Corley \& Tinker, 2016):

sex ratio $=\frac{\text { female flowers }+ \text { fruit bunches }}{\text { female flowers }+ \text { fruit bunches }+ \text { male flowers }}$

Furthermore, during the rotation of the harvesting (five times), each ripe FFB on each sample was harvested and weighed to investigate the impact of
P. pendula attack on the FFB production of the affected palm.

Data Analysis. The resulting data were analyzed for variance using GenStat $12^{\text {th }}$ edition software (VSN International UK). If there are significant differences between the attack categories, the data is further tested by Duncan's multiple range test with a confidence level of $5 \%(\alpha=0.05)$.

\section{RESULTS AND DISCUSSION}

Attack Intensity and Distribution Pattern of Bagworm P. pendula. Based on field observations, $87.45 \%$ of oil palms were attacked by bagworm $P$. pendula with intensity reaching $58.04 \%$. The composition of the attack was dominated by palm with very severe attack (score 4 ) with a proportion of $30.09 \%$, and higher than unattack palm plants $(12.55 \%)$.

Bagworm $P$. pendula attacks can occur at any age of the palm, but the highest intensities is generally occur in palms with overlapping fronds ( $\geq 8$ years old) (Susanto et al., 2015). Early instar larvae feed on the leaf's upper epidermis (Figure 1F), while the late instar larvae feed on the leaf's lower epidermis. Damage to this part of the epidermis causes the leaves to dry out and look like a burning appearance (Figure 1D-E). The attack of $P$. pendula generally starts from the lower frond and continues to the upper frond (Kamarudin \& Wahid, 2010).

The pattern of bagworm attacks in the experimental block tends to be in cluster (Figure 2). The cluster occurs because generally the bagworms move from the affected palm to another through the frond that have already overlap (Kamarudin \& Wahid, 2010; Susanto et al., 2012). This happens because the adult

Table 1. Scoring criteria to determine the level of damage to the oil palm canopy due to P. pendula attacks

\begin{tabular}{cl}
\hline Score & \multicolumn{1}{c}{ Remarks } \\
\hline 0 & Healthy palm with canopy of leaves that still look green without any symptoms of bagworm attack \\
1 & $\begin{array}{l}\text { Palm with mild symptom which means the symptoms of burning-like leaves have reached the canopy } \\
\text { of leaf circumference }>4\left(32^{\text {nd }} \text { leaf below) from above }\right.\end{array}$ \\
2 & $\begin{array}{l}\text { Palm with moderate symptom which means that the symptoms of burning-like leaves have reached the } \\
\text { canopy of leaf circumference } 3-4\left(24^{\text {th }} \text { to } 32^{\text {nd }} \text { leaves) from above }\right.\end{array}$ \\
3 & $\begin{array}{l}\text { Palm with severe symptoms, which means that symptoms of burning-like leaves have reached the } \\
\text { canopy of leaf circumference } 2-3\left(16^{\text {th }} \text { to } 24^{\text {th }} \text { leaves) from above }\right.\end{array}$ \\
4 & $\begin{array}{l}\text { Palm with very severe symptoms, which means that the symptoms of burning-like leaves have reached } \\
\text { the canopy of the leaf circumference }<2 \text { (first leaf to } 16^{\text {th }} \text { leaf) from above }\end{array}$ \\
\hline
\end{tabular}




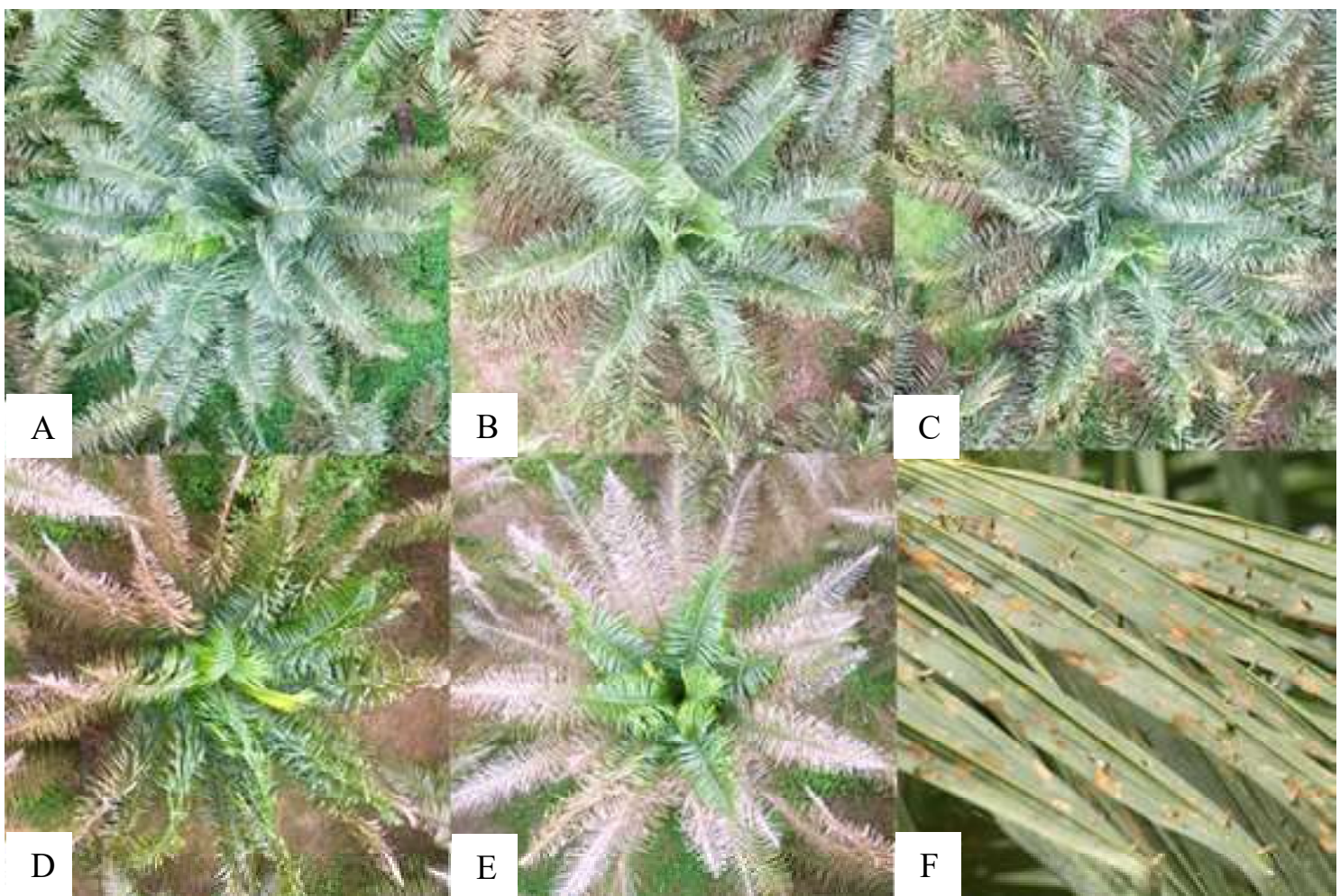

Figure 1. Aerial photographs of bagworm P. pendula attacks in various attack categories. (A) unattacked palm (score 0); (B) palms with mild symptoms (score 1); (C) palms with moderate symptoms (score 2); (D) palms with severe symptoms (score 3); (E). palms with very severe symptoms (score 4); (F) P. pendula attacks cause damage to the leaf epidermis.
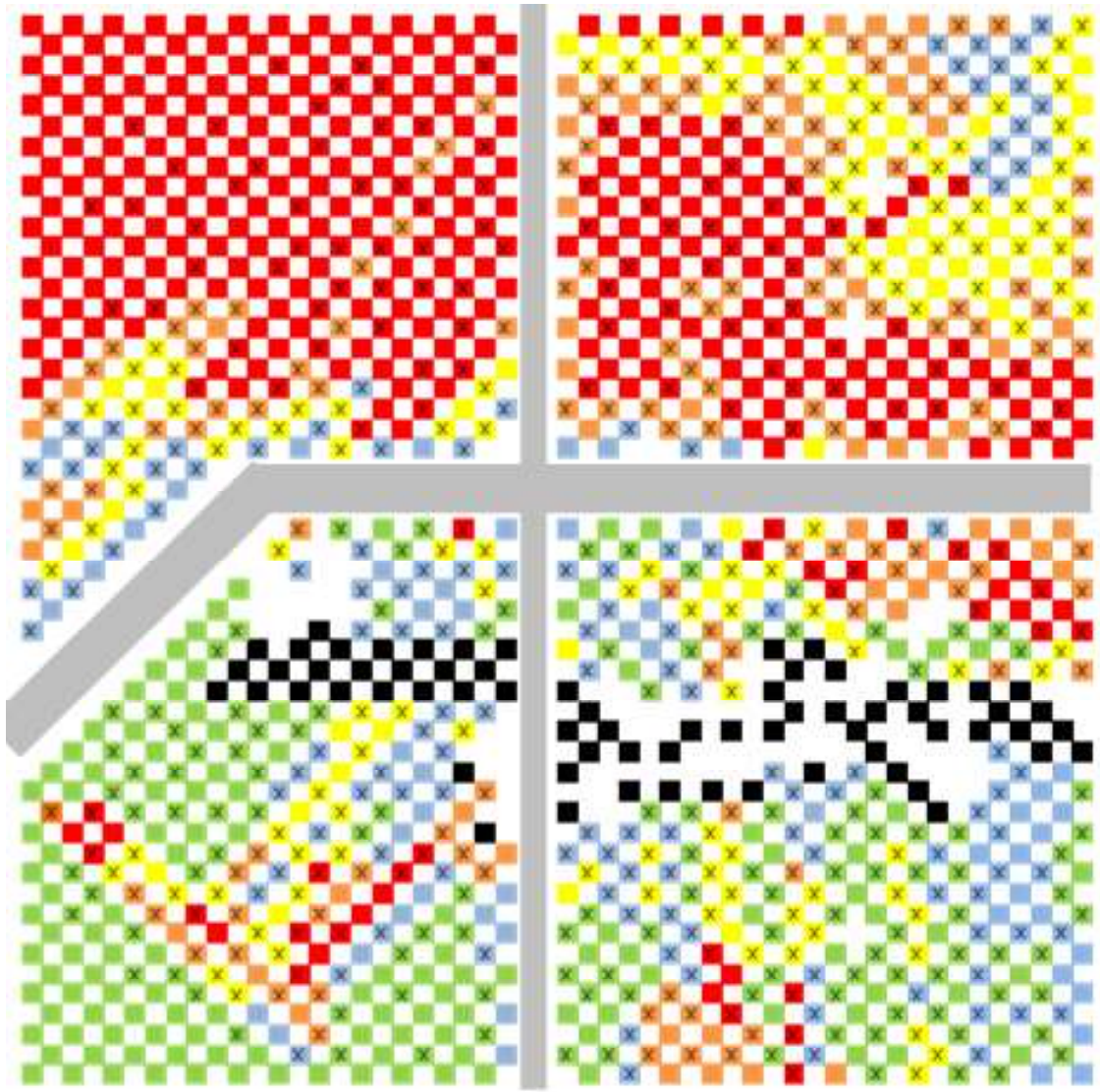

Score 0

Score 1

Score 2

Score 3

Score 4

X Palm sample

Figure 2. The map of $P$. pendula attack with various attack level categories (scores) on November 2016 at the oil palm observation block of planting year 2013. 
female bagworm has no wings and will remain in the bag until they lay eggs and die. The absence of these wings causes the distribution of bagworms to be slower and more limited around the initial point of attack. Based on this behavior, it can be assumed that the attack of the bagworm in the experimental block starts in the northwestern part.

Sex Ratio of the Oil Palm. Field observations showed that the sex ratio of plants was affected by the severity of $P$. pendula attacks. Palms with the highest attack intensity (score 4 or very severe symptoms) had the lowest sex ratio and were significantly different from healthy palms (Table 2). This shows that oil palms with very severe attack (score 4 ) produce more male inflorescences than the healthy palms (score 0 ). Meanwhile, palms with a score of 1-3 were not significantly different from healthy palms, although there was a tendency for a lower sex ratio.

The value of sex ratio was closely related to the process of sex differentiation that occurs long before the appearance of the inflorescences, which was between 18-24 months before (Djufry et al., 2000; Harahap, 2008). Normally, one male or female inflorescence can be formed on each frond (Corley \& Tinker, 2016). The formation of male or female oil palm inflorescences was strongly affected by the condition of the palm and the environment when the process took place. Palms experiencing stress due to environmental stresses such as mismatches in climatic and nutrient conditions or defoliation will produce more male inflorescences (Wood et al., 1973; Djufry et al., 2000; Adam et al., 2011; Darlan et al., 2016; Harahap et al., 2017). Marcelino \& Diaz (2016) has previously demonstrated the effect of defoliation on the number of female inflorescences produced by eight-year-old oil palm. Palms with less than 32 fronds/palm produce fewer female inflorescences or FFB than palms with normal number of frond (between 40-48 fronds/palm).

Production of FFB of Oil Palm Affected by $P$. pendula. The productivity of oil palm is determined by the number and weight of the FFB produced. Palms with moderate to very severe symptoms (score 2-4) had significantly less bunches than palms with healthy or mild symptoms (score 1) (Table 3 ). Although there were differences in the bunch number produced, there was no significant difference in the average of bunch

Table 2. Value of sex ratio of oil palm in various categories of $P$. pendula attacks

\begin{tabular}{|c|c|c|}
\hline Attack category (score) & Sex ratio $(\%)$ & Difference of sex ratio $(\%)$ \\
\hline 0 & $98.23 \pm 0.48 \quad \mathrm{a}$ & - \\
\hline 1 & $97.38+0.91 \mathrm{a}$ & 0.79 \\
\hline 2 & $96.35 \pm 1.01 \quad \mathrm{a}$ & 1.90 \\
\hline 3 & $96.43 \pm 1.05 \mathrm{a}$ & 1.74 \\
\hline 4 & $92.54 \pm 1.61 b$ & 5.53 \\
\hline
\end{tabular}

Values followed by the same letters is not significantly different based on Duncan's multiple interval test at significance level of $5 \%(\alpha=0.05)$.

Table 3. Average of bunch number, bunch weight and estimated FFB production of oil palm within various categories of $P$. pendula attacks

\begin{tabular}{|c|c|c|c|c|}
\hline Attack category & Bunch number & Bunch weight (kg) & $\begin{array}{l}\text { FFB production * } \\
(\mathrm{kg} / \text { palm/semester })\end{array}$ & $\begin{array}{c}\text { Decreased production } \\
(\%)\end{array}$ \\
\hline 0 & $12.14 \pm 3.86 \quad \mathrm{a}$ & $8.52 \pm 1.54 \quad \mathrm{a}$ & $103.49 \pm 3.01 \quad \mathrm{a}$ & - \\
\hline 1 & $11.39 \pm 3.48 \quad \mathrm{a}$ & $8.29 \pm 1.73 \quad a$ & $94.43 \pm 2.64 \quad b$ & 8.75 \\
\hline 2 & $9.88 \pm 3.60 \quad b$ & $8.28 \pm 1.36 \quad \mathrm{a}$ & $81.74 \pm 2.72 \quad \mathrm{c}$ & 21.02 \\
\hline 3 & $9.04 \pm 3.02 \quad b$ & $8.15 \pm 1.39 \quad \mathrm{a}$ & $73.68 \pm 2.25 \quad \mathrm{~d}$ & 28.80 \\
\hline 4 & $8.18 \pm 3.14 \quad c$ & $8.05 \pm 1.27 \quad \mathrm{a}$ & $65.87 \pm 2.31 \quad \mathrm{e}$ & 36.35 \\
\hline
\end{tabular}

Values in the same column followed by the same letters are not significantly different based on Duncan's multiple interval test at significance level of 5\% $(\alpha=0.05)$. Estimated FFB production for 6 months obtained from the bunch number $\mathrm{x}$ bunch weight. 
weight between palms attacked by $P$. pendula and healthy palms. The average bunch weight in all palms was in the range of $8.0-8.5 \mathrm{~kg}$, similar to the potential of bunch weight produced by five-year-old palms (Lubis, 2008). These results indicate that the effect of bagworm $P$. pendula or other defoliator pests was more clearly expressed in the bunch number than the bunch weight. Variations in the bunch number have also previously been reported to occur in palm under stressed conditions due to environmental cues or decreased photosynthetic activity because of defoliation (Henson, 1997; Henson, 1998; Henson \& Dolmat, 2004a). On the other hand, the bunch weight variable is generally not much affected by palm conditions or environmental stress (Lim \& Chan, 1998; Henson \& Dolmat, 2004b).

The attack intensity of $P$. pendula was negatively correlated to FFB production per palm (Figure 3 ). The higher the level of damage caused by $P$. pendula, the lower the FFB production per palm. The palms with the most severe level of damage (score 4) caused a loss of FFB yield of $36.35 \%$ (Table 3 ). The yield loss was affected by the lower bunch number produced due to defoliation in the affected palms.

Various studies have shown that the attack of leaf eating caterpillars with defoliation rates between $30-50 \%$ can cause a decrease in production of up to $40 \%$ in the first and second years after defoliation occurs (Wood et al., 1973; Basri et al., 1995; Syed \& Saleh, 1998; Kamarudin \& Wahid, 2010; Potineni \& Saravanan, 2013). The decrease in current year production was generally caused by the decreasing ability of palms to photosynthesize thereby disrupting the intake of assimilates for the development of flowers and fruit, while the decrease in production in the second year after defoliation was more due to the effect of a lower sex ratio (Corley \& Tinker, 2015; Woittiez et al., 2017). According to Henson \& Dolmat (2004a) as well as Cros et al. (2013) the number of bunches produced depends on the condition of the plant and the environment, especially during the process of flower formation.

When viewed from the total production of flower and FFB, healthy palms produce an average of 12.6 bunches per palm (Table 4). According to Turner \& Gillbanks (2003), the position of the anthesis or receptive flower is in the frond number 17 while the ripe FFB is in the frond number 31. Meanwhile, Corley \& Tinker (2016) stated that the receptive inflorescences are in the frond position number 20 while the ripe FFB is in the frond number 30 . This means that every healthy palm has the potential to produce 11-15 inflorescences or FFB. In the category of mild attack (score 1), the number of inflorescences and FFB production is not different from healthy palms. Conversely, palms with moderate to very severe attack categories (score 2-4) have a smaller bunch number. This indicates the existence of flower abortion on palms attacked by $P$. pendula.

Combres et al. (2013) predicted that the abortion process occurs 10 months after the stress on the oil palm. One of the triggers for flower abortion is the occurrence of stress on the palm which can be caused by defoliation in the palm canopy or unsuitable environmental conditions during the flower formation (Djufry et al., 2000; Corley \& Tinker, 2015; Harahap $\&$ Lubis, 2018). From Table 3 it can be seen that in general the higher the level of damage of palm canopy, the greater the potential for flower abortion. Flower

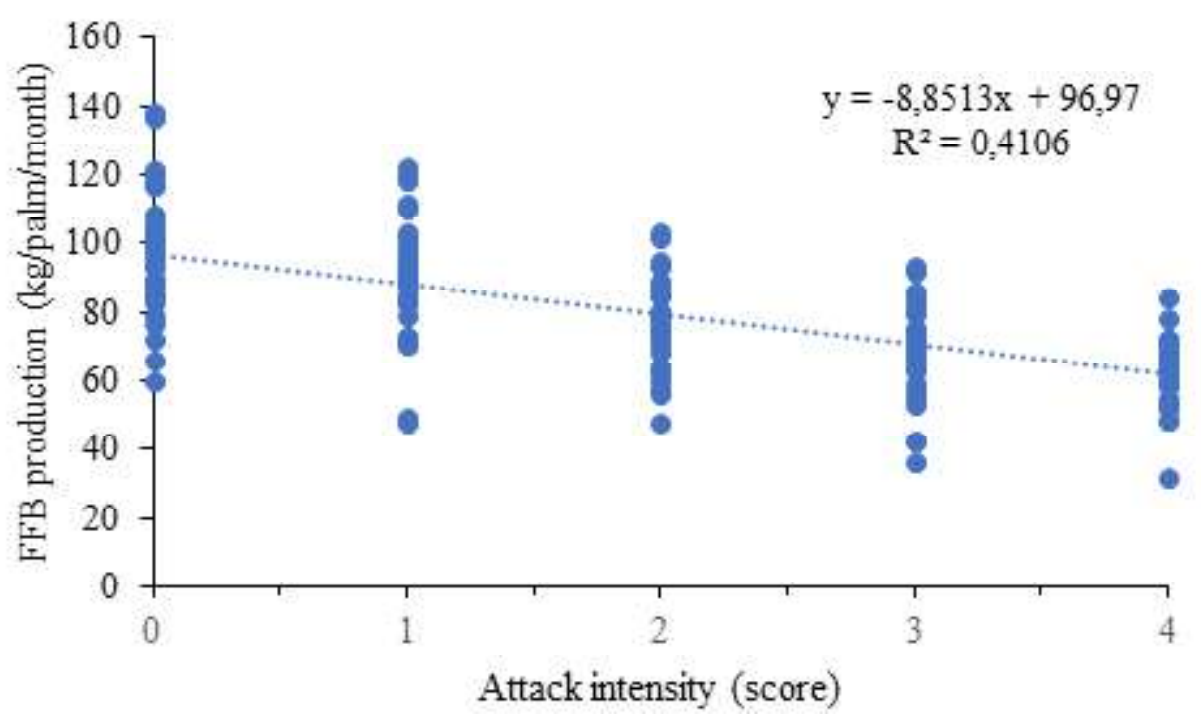

Figure 3. Relationship between $P$. pendula attack intensity and FFB production. 
Table 4. The number of flower and FFB produced by oil palm plants at various stages of $P$. pendula attack

\begin{tabular}{crcc}
\hline Attack category (score) & Number of flowers and fruit & Difference (\%) \\
\hline 0 & $12.6 \pm 0.34$ a & - \\
1 & $11.86 \pm 0.32$ & a & 5.87 \\
2 & $10.28 \pm 0.34$ & b & 18.41 \\
3 & $9.38 \pm 0.28$ & c & 25.56 \\
4 & $8.5 \pm 0.30$ & d & 32.54 \\
\hline
\end{tabular}

Values followed by the same letters is not significantly different based on Duncan's multiple interval test at significance level of $5 \%(\alpha=0.05)$.

abortions that occur in palms that are moderately (score 2 ), severely (score 3), and very severely (score 4) attacked are $18.41 \%, 25.56 \%$, and $32.54 \%$, respectively.

The above results have shown that attack of bagworm P. pendula can cause significant yield losses on oil palm. Potential decrease in production is also similar to those which has been reported in the attack of other species of bagworm, for instance, M. plana which ranges from 10-44\% (Basri \& Kevan, 1995; Sudharto et al., 1997; Pamuji et al., 2013). This shows that $P$. pendula is an important pest in oil palm plantations so that its presence in the field must be controlled to minimize yield losses.

\section{CONCLUSION}

Bagworm $P$. pendula tend to have a clustered attack pattern and caused defoliation of more than $50 \%$ in the canopy of an oil palm. The attack of $P$. pendula at moderate to very severe intensity (score $2-4$ ) causes a decrease in production of FFB by $21.02 \%$ to $36.35 \%$ and potential flower abortion from $18.41 \%$ to $32.54 \%$. The attack of $P$. pendula does not affect the average bunch weight of affected palms.

\section{ACKNOWLEDGMENT}

The research was fully supported by the Indonesian Oil Palm Research Institute. We would also like to show our gratitude to PT. Perkebunan Nusantara III for giving permission to conduct the research in Rambutan Estate.

\section{REFERENCES}

Adam H, Collin M, Richaud F, Beulé T, Cros D, Omoré A, Nodichao L, Nouy B, \& Tregear JW. 2011. Environmental regulation of sex determination in oil palm: current knowledge and insights from other species. Ann. Bot. 108(8): 1529-1537.

Ajambang W, Ardie SW, Volkaert H, Galdima M, \& Sudarsono S. 2015. Huge carbohydrate assimilates delay response to complete defoliation stress in oil palm (Elaeis guineensis Jacq.). Emir. J. Food Agr. 27(1): 126-137.

Apichatmeta K, Sudsiri CJ, \& Ritchie RJ. 2017. Photosynthesis of oil palm (Elaeis guineensis). Sci. Hortic. 214: 34-40.

Basri MW, Norman K, \& Hamdan AB. 1995. Natural enemies of the bagworm, Metisa plana Walker (Lepidoptera: Psychidae) and their impact on host population regulation. Crop Prot. 14(8): 637-645.

Basri MW \& Kevan PG. 1995. Life history and feeding behaviour of the oil palm bagworm, Metisa plana Walker (Lepidoptera: Psychidae). Elaeis. 7(1): 82-34.

Chung GF. 2012. Effects of pests and diseases on oil palm yield. In: Lai OM, Tan CP, \& Akoh CC (Eds.). Palm Oil: Production Processing Characterization, and Uses. pp. 163-210. Academic Press and AOCS Press, Amerika.

Combres JC, Pallas B, Rouan L, Mialet-Serra I, Caliman JP, Braconnier S, Soulie JC, \& Dingkuhn M. 2013. Simulation of inflorescence dynamics in oil palm and estimation of environment-sensitive phenologycal phases: a model based analysis. Funct. Plant Biol. 40(3): 263-279. 
Corley RHV \& Tinker PBH. 2016. The Oil Palm. Blackwell Science, Oxford.

Corley RHV \& Tinker PBH. 2015. The Oil Palm. Blackwell Science, Oxford.

Cros D, Flori A, Nodichao L, Omore A, \& Nouy B. 2013. Differential response to water balance and bunch load generates diversity of bunch production profiles among oil palm crosses (Elaeis guineensis). Trop. Plant Biol. 6(1): 26-36.

Darlan NH, Pradiko I, Winarna, \& Siregar HH. 2016. Dampak El Niño 2015 terhadap performa tanaman kelapa sawit di Sumatera Bagian Tengah dan Selatan. J. Tanah dan Iklim. 40(2): 113120.

Djufry F, Handoko, \& Koesmaryono Y. 2000. Model fenologi tanaman kelapa sawit. J. Agromet. 15(12): $33-42$.

Harahap IY. 2008. Kajian diferensiasi jenis kelamin pada pembentukan bunga kelapa sawit (Elaeis guineensis Jacq.) melalui pendekatan kuantitatifstatistik. J. Pen. Kelapa Sawit. 16(1): 47-54.

Harahap IY \& Lubis MES. 2018. Dinamika air dan fasefase perkembangan pembungaan penentu produktivitas kelapa sawit. J. Pen. Kelapa Sawi. 26(3): 101-112.

Harahap IY, Sumaryanto, Hidayat TC, Fauzi WR, \& Pangaribuan Y. 2017. Produksi jenis kelamin tandan bunga kelapa sawit dan responsnya terhadap perlakuan exogenous hormone tanaman pada lahan yang mengalami kekeringan. J. Pen. Kelapa Sawit. 25(1): 31-46.

Henson IE. 1997. Analysis of oil palm productivity. 1. the estimation of seasonal trends in bunch dry matter production. Elaeis. 9(2): 69-77.

Henson IE. 1998. Notes on oil palm productivity. 1. productivity at two contrasting sites. J. Oil Palm Res. 10: 57-67.

Henson IE \& Dolmat MT. 2004a. Seasonal variation in yield and developmental processes in an oil palm density trial on a peat soil: 1 . yield and bunch number components. J. Oil Palm Res. 16(2): 88105.

Henson IE \& Dolmat MT. 2004b. Seasonal variation in yield and developmental processes in an oil palm density trial on a peat soil: 2 . bunch weight components. J. Oil Palm Res. 16(2): 106-120.
Kamarudin NHJ \& Wahid MB. 2010. Interactions of the bagworm, Pteroma pendula (Lepidoptera: Psychidae), and its natural enemies in an oil palm plantation in Perak. J. Oil Palm Res. 22(April): 758-764.

Lim KC \& Chan KW. 1998. Bunch components studies over the past two decades. In: Rajanaidu N, Henson IE, \& Jalani BS (Eds.). Proc. 1996 Int. Conf. Oil and Kernel Production in Oil Palm A Global Perspective. pp. 133-150. Kuala Lumpur, PORIM.

Lubis AU. 2008. Kelapa Sawit (Elaeis guineensis Jacq.) di Indonesia. Pusat Penelitian Kelapa Sawit.

Marcelino J \& Diaz E. 2016. Frond pruning enhanced the growth and yield of eight-year-old oil palm (Elaeis guineensis Jacq.). Ann. Trop. Res. 38(2): 96-105.

Masijan Z, Kamarudin N, Moslim R, Sintik AG, Ahmad SNH, \& Ali SRA. 2015. Bunch moth, Tirathaba rufivena (Lepidoptera: Pyralidae) infestation census from oil palm plantation on peat soil in Sarawak. Serangga. 20(1): 43-53.

Pamuji R, Rahardjo BT, \& Tarno H. 2013. Populasi dan serangan hama ulat kantung Metisa plana Walker (Lepidoptera: Psychidae) serta parasitoidnya di perkebunan kelapa sawit Kabupaten Donggala, Sulawesi Tengah. J. HPT. 1(2): 58-71.

Pangaribuan R, Marheni, \& Lubis L. 2017. Tingkat serangan ulat kantung Cremastopsyche pendula Joannis pada tanaman kelapa sawit menghasikan dan belum menghasilkan di Rambong Sialang Estate PT PP. London Sumatera Indonesia. $J$. Agroekoteknologi. 5(4): 922-931.

Potineni K \& Saravanan L. 2013. Natural enemies of oil palm defoliators and their impact on pest population. Pest Manag. Hortic. Ecosys. 19(2): 179-184.

Priwiratama H, Rozziansha TAP, \& Prasetyo AE. 2018. Efektivitas flubendiamida dalam pengendalian ulat api Setothosea asigna van Eecke, ulat kantung Metisa plana Walker, dan penggerek tandan Tirathaba rufivena Walker serta pengaruhnya terhadap aktivitas kumbang penyerbuk Elaeidobius kamerunicus Faust. J. Pen. Kelapa Sawit. 26(3): 129-140. 
Sudharto P, Djamin A, \& Pardede D. 1997. Pengendalian ulat pemakan daun kelapa sawit secara terpadu. In: Pertemuan Teknis Kelapa Sawit 1997: Pengendalian Oryctes rhinoceros dan UPDKS secara terpadu, 1997 Jakarta. Pusat Penelitian Kelapa Sawit.

Susanto A, Prasetyo AE, Priwiratama H, Rozziansha TAP, Simanjuntak D, Sipayung A, Purba RY, Sudharto, \& de Chenon RD. 2015. Kunci Sukses Pengendalian Hama dan Penyakit Kelapa Sawit. Pusat Penelitian Kelapa Sawit, Medan.

Susanto A, Prasetyo AE, Simanjuntak D, Rozziansha TAP, Priwiratama H, Sudharto P, de Chenon RD, Sipayung A, Widi AT, \& Purba RY. 2012. EWS: Ulat Api, Ulat Kantung, Ulat Bulu. Pusat Penelitian Kelapa Sawit, Medan.

Syed RA \& Saleh HA. 1998. Integrated pest management of bagworms in oil palm plantation of PT. PP. London Sumatra Indonesia TBK (With particular reference to Mahasena corbetti Tams) in North Sumatra. The International Oil Palm Conference 1998. pp. 386-391. Indonesian Oil Palm Research Institute. Nusa Dua, Bali.
Turner PD \& Gillbanks R. 2003. Oil Palm Cultivation and Management. Incorporated Society of Planters, Malaysia.

Woittiez LS, van Wijk MT, Slingerland M, van Noordwijk M, \& Giller KE. 2017. Yield gaps in oil palm: a quantitative review of contributing factors. Eur. J. Agron. 83(Februari): 57-77.

Wood BJ, Corley RHV, \& Goh KH. 1973. Studies on the effect of pest damage on oil palm yield. In: Wastrie RL \& Eerp DA (Eds.). Advanced in Oil Palm Cultivation. pp. 20. The Incorporate Society of Planters. 